NBER WORKING PAPER SERIES

\title{
TAXES, TECHNOLOGY TRANSFER, AND THE R\&D ACTIVITIES OF \\ MULTINATIONAL FIRMS
}

James R. Hines, Jr.

Working Paper No. 4932

\author{
NATIONAL BUREAU OF ECONOMIC RESEARCH \\ 1050 Massachusetts Avenue \\ Cambridge, MA 02138 \\ November 1994
}

1 thank Jeffrey Geppert for outstanding research assistance, and Adam Jaffe and James Poterba for helpful comments on an earlier draft. Financial support from the NSF (Grant No. SES9209373) and NBER is gratefully acknowledged. This paper is part of NBER's research programs in Intemational Trade and Investment, Productivity, and Public Economics. Any opinions expressed are those of the author and not those of the National Bureau of Economic Reseirch.

1994 by James R. Hines, Jr. All rights reserved. Short sections of text, not to exceed two paragraphs, may be quoted without explicit permission provided that full credit, including (C) notice, is given to the source. 
NBER Working Paper \#4932

November 1994

\title{
TAXES, TECHNOLOGY TRANSFER, AND THE R\&D ACTIVTTIES OF MULTINATIONAL FIRMS
}

\begin{abstract}
Multinational firms that use domestic technologies in foreign locations are required to pay royalties from foreign users to domestic owners. Foreign governments often tax these royalty payments. High royalty tax rates raise the cost of imported technologies. This paper examines the effect of royalty taxes on the local R\&D intensities for foreign affiliates of multinational corporations, looking both at foreign-owned affiliates in the United States and at American-owned affiliates in other countries. The results indicate that higher royalty taxes are associated with greater $R \& D$ intensity on the part of affiliates, suggesting that local $R \& D$ is a substitute for imported technology.
\end{abstract}

James R. Hines, Jr.

John J. Kennedy School of Government

Harvard University

79 John F. Kennedy Street

Cambridge, MA 02138

and NBER 


\section{Introduction.}

Many governments encourage the development and use of new technologies within the borders of their countries. It is not difficult to understand why they do so. It is widely believed that the positive correlation between local economic affluence and the presence of technologically advanced industries implies that the use of new technologies enhances overall productivity. More direct evidence generally supports the conclusion that the economic benefits of research and development (R\&D) activity extend to local firms other than those undertaking the R\&D. ${ }^{1}$ Since there are reasons to expect that externality-generating $R \& D$ activites may be underprovided by markets in which developers of new technologies do not capture all of the economic benefits that the technologies provide, various governments offer R\&D-related tax subsidies. ${ }^{2}$ Governments that do not uffer R\&D tax subsidies are often concerned that perhaps they should. There are, however, many open questions about the impact of tax policy on the level of R\&D.

Tax systems influence the level and content of $R \& D$ activity through a variety of channels. This paper focuses on R\&D by multinational firms, and the impact of one particular set of taxes: withholding taxes on cross-border royalty payments. Firms that develop new technologies in their hume countries and use the technologies in foreign locations are required to pay royalties from foreign affiliates to domestic parent companies. Governments tax these royalty payments. High tax

'See Griliches (1991) and Nadiri (1993) for surveys of empirical measures of productivity spillovers from $R \& D$ activities.

In theory, the welfare consequences of subsidizing R\&D are ambiguous, because competitive pressures might generate too much $R \& D$ in certain industries in the absence of a subsidy, and because foreign competitors may benefit from domestic subsidies (or in other ways influence the domestic market). See Dixit (1988) and Reinganum (1989) for surveys of the theory. The United States introduced the Research and Experimentation Tax Credit, and increased the tax deductibility of the R\&D expenses of certain multinational corporations, in the Economic Recovery Tax Act of 1981. This legislation appears to have been motivated by consideration of economic externalities, though the focus of Congressional sentiment as described in U.S. Congress, Joint Committee on Taxation (1981) is on comparisons of U.S. research intensity with the research intensities of other countries. 
rates make royalties, and the technology imports that they accompany, more expensive for the foreign affiliates that pay the taxes.

In theory, higher costs of imported technology might encourage or discourage local $R \& D$ by affiliates of multinational corporations. If local $R \& D$ is complementary with imported technology, then high royalty tax rates should discourage local R\&D, while if local R\&D is a substitute for imported technology, then high royalty tax rates should encourage local R\&D.

This paper has two objectives. The first is to identify the degree to which R\&D activity by multinational firms is sensitive to local tax conditions. The second objective is to determine whether imported technology and local R\&D are complements or substitutes.

The resuits suggest that $R \& D$ responds significantly to local tax rates, and that local $R \& D$ is a substitute for imported technology. These results appear both in the behavior of American investors in other countries, and in the behavior of foreign investors in the United States. Firms appear to react to high royalty tax rates by paying fewer royalties and performing additional R\&D locally. To the extent that royalty payments reflect actual technology transfer (rather than adept accounting practices), the behavior of multinational firms implies that local R\&D is a substitute for imported technology.

Section 2 of the paper briefly describes the tax treatment of multinational tirms, paying particular attention to technology-related issues. Section 3 describes a simple model of firm behavior that traces the link between taxation and the degree of complementarity or substitutability of local R\&D and imported technology. Section 4 describes the data that serves as the basis of the empirical work. Section 5 presents evidence on the relationship between royalty tax rates in foreign countries and the R\&D intensities of local affiliates of American multinational firms. Section 6 examines the same relationship for foreign firms investing in the United States. Section 7 is the conclusion. 


\section{Multinational Firms, Taxation, and International Technology Transfer.}

This section examines the role of multinational firms in international technology transfer, and reviews the tax treatment of $R \& D$ expenditures and royalty receipts by multinational firms.

\section{International Technology Transfer}

There is considerable interest in understanding the role that multinational firms play in transferring technologies across borders. There are two methods by which multinational firms provide new technologies to the countries in which they invest. The first method is to develop new technologies locally, through R\&D or other similar type of activity. The second method is to import technologies produced elsewhere.

The foreign affiliates of American firms use both methods to bring technologies to the countries in which they operate, and there exists sufficient information to assess quantitatively the relative significance of each method. Direct information on the R\&D activities of the foreign affiliates of U.S. firms is reported in surveys conducted by the United States Commerce Department. Information on technology imports by these affiliates is considerably sketchier. One can, however, infer the approximate magnitude of technology imports from royalties paid by the affiliates to U.S. parent firms and third parties in other countries, since royalty payments should, in principle, reflect the values of imported technologies.

Table 1 reports detailed information about the aggregate technology-related behavior of the foreign affiliates of U.S. firms in 1982 and 1989 . It is noteworthy that these affiliates paid more in royalties to their parent firms ( $\$ 9.8$ billion in 1989$)$ than they spent on R\&D ( $\$ 7.9$ billion in 1989), though, as the table indicates, there was extensive use of both methods of technology dequisition. The survey distinguishes two categories of R\&D expenditure: R\&D by affiliates for 
themseives, and $R \& D$ by affiliates for others (the latter of which is R\&D performed on a contract basis). R\&D by affiliates for themselves constitutes roughly $80 \%$ of their total R\&D expenditures.

American firms spend a considerable amount of money on R\&D performed in foreign countries, but in recent years, foreign-owned firms in the United States have spent even more than that on R\&D performed here. Figure 1 illustrates the R\&D expenditure levels of foreign affiliates of U.S. firms and foreign-owned firms in the United States over the $1977-1990$ period. Due to the R\&D-intensity of the U.S. economy relative to the rest of the world, and the strength of foreign direct investment into the United States since 1973, foreign firms have spent more on R\&D inside the United States than American firms have spent on R\&D outside the United States in every year since 1982, and the gap between the two expenditure levels is widening (see Figure 1). ${ }^{3}$

There is considerable interest in the role of multinational firms in transferring technology across borders, and the impact that government policy can bave on the rate and direction of technology transfer. Though these issues have been extensively studied, ${ }^{4}$ one of the open questions is the degree to which imported technology is a substitute or complement for local R\&D.

\section{US Taxation of Foreign Income}

${ }^{3}$ Exchange rate fluctuations can confound the interpretation of Figure 1, since changes in the value of the dollar relative to foreign currencies affect the dollar-denominated relative magnitudes of $R \& D$ performed in the United States and abroad, even if nominal expenditures are unchanged. This consideration is not significant in this case, however, since a simple adjustment for the changing value of the dollar relative to a trade-weighted average of foreign currencies produces a figure that very closely resembles Figure 1.

${ }^{4}$ See, for example, Teece (1976), Germidis (1977), Mansfield, Teece, and Romeo (1979), Mansfield and Romeo (1980), Davidson and McFetridge (1984), Lipsey, Blomstrom, and Kravis (1990), Zejan (1990), Blomstrom (1991), Ethier and Markusen (1991), Wang and Blomstrom (1992), and Blomstrom and Kokko (1993). These studies together consider the effect of a large number of variables on technology transfer and R\&D activity, though they do not consider the effect of royalty tax rates on local $\mathrm{R} \& \mathrm{D}$ intensities.

${ }^{5}$ Parts of this brief description of the tax system are excerpted from Hines (1991). 
The United States taxes income on a "residence" basis, meaning that American corporations and individuals owe taxes to the U.S. government on all of their worldwide income, whether earned in the United States or not. The top U.S. corporate tax rate is now 35 percent. Since foreign profits are usually taxed in host countries, U.S. law provides a foreign tax credit for income taxes (and related taxes) paid to foreign governments, in order not to subject American multinationals to double taxation. The foreign tax credit mechanism provides that an American corporation earning $\$ 100$ in a foreign country with a 12 percent tax rate (and a foreign tax obligation of $\$ 12$ ) pays only $\$ 23$ to the U.S. government, since its U.S. corporate tax liability of $\$ 35$ (35 percent of $\$ 100)$ is reduced to $\$ 23$ by the foreign tax credit of $\$ 12$. The foreign tax credit is, however, limited to U.S. tax liability on foreign income; if, in the example, the foreign tax rate were 50 percent, then the firm pays $\$ 50$ to the foreign government but its U.S. foreign tax credit is limited to $\$ 35$. Hence an American firm receives full tax credits for its foreign taxes paid only when it is in a "deficit credit" position, i.e., when its average foreign tax rate is less than its tax rate on domestic operations. A firm has "excess credits" if its available foreign tax credits exceed U.S. tax liability on its foreign income. Firms average together their taxable incomes and taxes paid in all of their foreign operations in calculating their foreign tax credits and the foreign tax credit limit. ${ }^{6}$

Deferral of U.S. taxation of certain foreign earnings is another important feature of the U.S. international tax system. An American parent firm is taxed on its subsidiaries' foreign

\footnotetext{
'In order to qualify for the foreign tax credit, firms must own at least $10 \%$ of a foreign affiliate, and only those taxes that qualify as income taxes are creditable. Furthermore, income is broken into different functional "baskets" in the calculation of applicable credits and limits. Income earned and taxes paid in the conduct of most types of active foreign business operations are grouped in one "basket; " petroleum industry income is grouped in a separate "basket;" and there are separate "baskets" for items such as passive income earned abroad. The "basket" distinctions imply that a firm might simultaneously have excess foreign tax credits in the petroleum "basket" (which is common, since foreign tax rates on oil income are typically quite high) and deficit foreign tax credits in the active income "basket." Such a firm would have to pay some U.S. tax on its active foreign income, even though it has excess foreign tax credits on its petroleum income.
} 
income only when returned ("repatriated") to the parent corporation. This type of deferral is available only to foreign operations that are separately incorporated in foreign countries ("subsidiaries" of the parent) and not to consolidated ("branch") operations. The U.S. government taxes branch profits as they are eamed, just as it would profits earned within the United States.

The deferral of U.S. taxation may create incentives for firms with lightly-taxed foreign earnings to delay repatriating dividends from their foreign subsidiaries. ${ }^{7}$ This incentive arises in those cases in which firms expect never to repatriate their foreign earnings, or if they anticipate that future years will be more attractive for repatriation (either because domestic tax rates will be lower, or because future sources of foreign income will generate excess foreign tax credits that can be used to oftset U.S. tax liability on the dividends). It appears that, in practice, American multinationals tend to pay dividends out of their more heavily taxed foreign earnings first. ${ }^{9}$ Consequently, the average tax rate that firms face on their foreign income need not exactly equal the average foreign tax rate faced by their branches and subsidiaries abroad.

Branch earnings and dividends from subsidiaries represent only two forms of foreign income for U.S. income tax purposes. Interest received from foreign sources also represents foreign income, though foreign interest receipts are often classified within their own "basket" and hence are

\footnotetext{
${ }^{7}$ The incentive to defer repatriation of lightly taxed subsidiary earnings is attenuated by the Subpart $F$ provisions, introduced in U.S. law in 1962, that treat a subsidiary's passive income, and income invested in U.S. property, as if it were distributed to its American owners, thereby subjecting it to immediate U.S. taxation. The Subpart F rules apply to controlled foreign corporations, which are foreign corporations owned at least $50 \%$ by American persons holding stakes of at least $10 \%$ each. Controlled foreign corporations that reinvest their foreign earnings in active businesses can continue to defer their U.S. tax liability on those earnings. See Hines (1994b), Hines and Rice (1994) and Scholes and Wolfson (1992) for the behavioral implications of these rules.
}

${ }^{8}$ It is interesting to note that the deferral of US tax liability does not itself create an incentive to delay paying dividends from foreign subsidiaries, since the US tax must be paid eventually. See Hartman (1985).

${ }^{9}$ See the evidence presented in Hines and Hubbard (1990). 
nut averaged with other income in calculating the foreign tax credit. Royalty income received from foreigners, including foreign affiliates of U.S. firms, is also foreign source income. Foreign governments often impose moderate taxes on dividend, interest, and royalty payments from foreign affiliates to their American parent companies; these withholding ${ }^{10}$ taxes are fully creditable against an American taxpayer's U.S. tax liability on foreign income.

\section{The Tax Treatment of R\&D Expenditures and Royalty Receipts}

Ameriean multinational firms that perform R\&D in the United States intending to use the resulting technology both in the United States and abroad face a complex tax treatment of their transactions. Since passage of the Tax Reform Act of 1986, American multinationals are no longer allowed to deduct 100 percent of their U.S. R\&D expenses against their U.S. tax liabilities. Instead, U.S. law requires American firms to allocate R\&D expenses between U.S. and foreign source based on the fraction of a firm's sales that are foreign." The practical importance of this system is that firms with excess foreign tax credits receive usable tax deductions for only a fraction (equal to the ratio of dornestic sales to total worldwide sales) of their U.S. R\&D expenses. This system is based on the idea that multinational firms performing R\&D in the United States use only a fraction of the output of their R\&D activities to enhance their sales in the United States, and consequently, that only a fraction of their R\&D costs should be deductible against U.S.-source income.

Royalties received by American parent firms for $R \& D$ used abroad represent taxable

\footnotetext{
${ }^{10}$ Taxes on cross-border flows, such as dividends, interest, and royalties, are known as "withholding" taxes due to some of the specifics of their administration. Strictly speaking, these taxes represent obligations of the recipients of the cross-border flows and not the payors; this arrangement permits immediate full crediting of withholding taxes by recipients who are eligible to claim foreign tax credits. The taxes are called "withholding" taxes because the local payor is the withholding agent for the tax, and is therefore liable to its host government for full payment of the taxes.
}

${ }^{11}$ See Hines (1993, 1994a) for descriptions of the precise formulas used and quantitative assessments of their impact on R\&D spending levels. 
foreign-source income of the American firms. American firms with deficit foreign tax credits must pay U.S. income tax on these royalty receipts, while firms with excess foreign tax credits can apply the excess credits against U.S. taxes due on the royalties, thereby eliminating the U.S. tax liability created by the royalty receipts.

Most of the world's governments impose withholding taxes on cross-border royaity payments from affiliates located within their countries. These royalty tax rates are frequently reduced according to the terms of bilateral tax treaties. For example, the United States imposes a 30 percent tax on royalties paid to foreign corporations, but this tax rate is often reduced, in some cases to zero, when recipients of royalty payments are located in countries with whom the United States has a tax treaty in force.

\section{Framework for Analysis.}

This section analyzes the implications of systems of international taxation for the R\&D behavior of multinational firms.

Consider a multinational firm that establishes a foreign affiliate to produce and sell goods in the foreign country in which the affiliate is located. ${ }^{12}$ The affiliate generates sales using local inputs of capital, labor, and intermediate products; in addition, the affiliate uses technology from its parent and the technology it generates on its own to produce goods for sale. The reduced-form function that describes the impact of technologies on the affiliate's sales can be formalized as: $S\left(R, R^{*}, \phi\right)$, in which $S$ denotes sales in the local (foreign) market, $R$ is technology provided by the parent firm to the affiliate in this market, $R^{*}$ is the technology that the affiliate generates on its own,

\footnotetext{
${ }^{12}$ This analysis abstracts from the possibility that the activities of foreign affiliates directly enhance the sales of its domestic parent firm. One of the practical difficulties that American firms encounter in such situations is that royalties paid by U.S. parents to their foreign affiliates are severely taxdisadvantaged. See Hines (1994a) for a discussion of this issue.
} 
and $\phi$ denotes other features of the local market (as well as the affiliate's profit-maximizing employment of local factors).

American tax law and the tax laws of most other countries ${ }^{13}$ require that foreign affiliates pay rents or royalties to their parent firms for the fair market value of technologies transferred from the parent firms to the affiliates. Of course, in practice is it frequently difficult to establish the fair market value of technology transferred from one party to another within a controlled group, since there may exist no market prices for the types of technology in question. In such cireumstances, tax-avoiding firms that transfer technology from the parent to its foreign affiliates often have incentives to select royalty payments that transfer taxable income out of high-tax jurisdictions and into low-tax jurisdictions. Governments are aware of this incentive, and try to use their entorcement power to prevent royalties from deviating too greatly from reasonable values. ${ }^{14}$

One way to describe government enforcement efforts is to introduce an additional cost that firms bear when royalties deviate from market values. The cost includes the cost that firms incur in justifying their royalty delcarations to tax authorities. If this adjustment cost rises sufficiently with the size of the deviation of reported royalties from market values, then it will ultimately limit the degree to which firms modify royalty payments simply for tax purposes.

A quadratic model of adjustment costs provides a convenient framework to use in analyzing the impact of government enforcement efforts. One can distinguish $\mathrm{R}$, the true value of transferred technology, from $r$, the royalty paid to the parent firm by the affiliate receiving the rechnology. If the rate of adjustment cost is quadratic in the deviation of declared royalties from the tachnology's market value, then adjustment costs equal $\alpha\left[(R-r)^{2} / R^{2}\right]$ for each unit of technology

${ }^{13}$ Of the twenty-five industrialized countries surveyed by Lawlor (1985), twenty-four apply the arm's length principle to the taxation of related-party transactions; Hong Kong is the lone exception.

${ }^{14}$ For evidence on the overall effectiveness of transfer price enforcement, see Kopits (1976), Grubert and Mutti (1991), Harris et al. (1993), and Hines and Rice (1994). 
transferred. $\alpha$ is taken to be a constant parameter. Total adjustment costs equal the product of $R$ and this term, or $\alpha(\mathrm{R}-\mathrm{r})^{2} / \mathrm{R}$.

The affiliate's technology-related taxable income represents the difference between sales revenue generated by the technology and the affiliate's costs. These costs include the affiliate's own R\&D expenditures, the royalties it pays to the parent firm, and the adjustment cost. ${ }^{\text {is }}$ The parent firm receives a royalty from its affiliate, and may incur a cost of producing the technology that it transfers to the affiliate. In order to fix ideas for the analysis that follows, the model describes the behavior of a multinational firm that has excess foreign tax credits and that values on a one-for-one basis its after-tax profits in foreign subsidiaries. ${ }^{16}$ The multinational firm maximizes after-tax profits, $\pi$ :

$$
\pi=\left(1-\tau^{*}\right)\left[S\left(\mathrm{R}, \mathrm{R}^{*}, \phi\right)-\mathrm{R}^{*}-\mathrm{r}-\alpha(\mathrm{R}-\mathrm{r})^{2} / \mathrm{R}\right]+\left(1-\mathrm{w}^{*}\right) \mathrm{r}-\mathrm{cR}
$$

\footnotetext{
${ }^{15}$ This treatment of the foreign affiliate abstracts from its activities that are unaffected by $R \& D$ activities or technology imports. The affiliate, and not the parent firm, is assumed to bear the adjustment cost because doing so simplifies the algebra that follows. A more general treatment that allocates adjustment costs between affiliates and parent firms yields qual itatively similar results. See, for example, the treatment of adjustment costs in Hines and Rice (1994).

${ }^{i 6} \mathrm{~A}$ firm values its subsidiaries' profits on a one-for-basis either if there is no tax due upon repatriation or if the firm can use deferral strategies of the type described in Hines and Rice (1994) to reduce the present value of repatriation taxes. A firm with deficit foreign tax credits maximizes an expression that is similar to (1), with the difference that the terms $\left(1-\tau^{*}\right)$ and $\left(1-w^{*}\right)$ are replaced by $(1-\tau)$, in which $\tau$ is the home-country tax rate. The first-order conditions describing the behavior of such a firm imply that the firm sets $r=R$, and that, in this static setting, host-country tax rates do not influence its behavior. In practice, the behavior of American multinational firms should reflect some kind of average of these two extremes. The analysis that follows assumes that all American firms have excess foreign tax credits, so, to the extent that many firms do not, the empirical estimates understate the responsiveness of the affected group to local tax conditions. The home countries of foreign investors in the United States have tax systems that differ considerably in their treatments of R\&D expenditures and royalty and dividend income from foreign sources. The empirical work in this paper distinguishes home-country tax systems only by whether firms are permitted to claim foreign tax credits, which omits some more subtle distinctions and may, thereby, introduce measurement error in the tax variables.
} 
in which $\tau^{*}$ is the foreign statutory tax rate, $w^{*}$ is the withholding tax rate imposed by the foreign government on outgoing royalty payments, and $c$ is the per-unit cost incurred by the parent firm to develop and/or transfer the technology represented by $\mathbf{R}$. The first term in expression (1) represents the after-foreign-tax profits earned by the affiliate; the second term is the parent firm's afterwithholding-tax royalty receipts; and the third term is the parent firm's cost of developing the technology that it transfers to the aftiliate. In some cases, parent firms costlessly transfer to their subsidiaries technologies developed for other purposes, so it is possible that $c=0$.

The first-order condition describing the firm's optimal choice of $r$ is:

$$
\left(1-\tau^{*}\right)[2 \alpha(\mathrm{R}-\mathrm{r}) / \mathrm{R}-1]+\left(1-\mathrm{w}^{*}\right)=0
$$

which yields:

$$
\mathrm{r}=\mathrm{R}\left\{1+\left(\tau^{*}-\mathrm{w}^{*}\right) /\left[2 \alpha\left(1-\tau^{*}\right)\right]\right\}
$$

The first-order condition describing the firm's optimal choice of $R$ is:

$$
\left(1-\tau^{*}\right)\left[\partial S / \partial R-\alpha(R-r)(R+r) / R^{2}\right]-c=0
$$

Imposing (3) and simplifying yields:

$$
\partial \mathrm{S} / \partial \mathrm{R}=\mathrm{c} /\left(1-\tau^{*}\right)+\left(\mathrm{W}^{*}-\tau^{*}\right) /\left(1-\tau^{*}\right)-\left(W^{*}-\tau^{*}\right)^{2} /\left[4 \alpha\left(1-\tau^{*}\right)^{2}\right]
$$

The first-order condition describing the firm's optimal choice of $R^{*}$ is considerably simpler: 
The conditions (3), (5), and (6) characterize the multinational firm's optimal interior choices of $R, R^{*}$, and $r$. Inspection of (5) and (6) indicates that taxation does not affect the required marginal productivity of $R \& D$ performed in the foreign location, while taxation does affect the required marginal productivity of $R \& D$ performed in the home country. Consequently, as long as tax rates are set in a manner that is exogenous to the unobservable factors that determine R\&D intensity, it is possible to use the tax variables that appear on the right side of (5) to estimate the extent to which domestic technology is a substitute or complement for foreign R\&D.

\section{Data.}

There are two available sources of detailed information on the R\&D activities of multinational firms located in a large number of countries. The first source is the 1989 Benchmark Survey of the Bureau of Economic Analysis (BEA) of the United States Department of Commerce. This survey, the results of which are reported in United States Department of Commerce (1992), is the most recent comprehensive survey of the activities of the foreign affiliates of American multinational firms. The survey covers activities during 1989 . In order to protect the confidentiality of survey respondents, BEA does not divulge the responses of individual firms, and reports country aggregates only for those countries in which there are sufficient numbers of U.S. firms with sizable activities that aggregate figures do not reveal information about individual firms. Useful R\&D and royalty data are available for affiliates in 43 foreign countries for 1989.

The second source of information is the 1987 survey of foreign direct investment in the United States, reported in United States Department of Commerce (1990). This survey describes the activities of foreign-owned firms in the United States during 1987. Due to data suppressions and 
other limitations, useful data are available on investors from 27 different countries during 1987.

The goal of the statistical work is to examine the relationship between royalty tax rates and levels of R\&D activity, both for American firms investing in foreign countries and for foreign firms investing in the United States. The difficulty that such a study encounters is that R\&D levels differ for reasons that have nothing to do with tax rates. One nontax factor that is clearly associated with $R \& D$ spending is the degree of $R \& D$ intensity in the countries in which multinational firms have operations. The foreign affil iates of American multinationals located in countries whose economies are R\&D-intensive tend to perform more R\&D than do aftiliates located in other countries. Similarly, foreign-owned affiliates in the United States tend to invest more in R\&D if their parent firms are located in technologically-intensive countries. ${ }^{17}$

Information is available from the National Science Foundation (1991) on the R\&D intensities of a large number of countries. The National Science Foundation constructs indices that reflect national $R \& D / G N P$ ratios; due to data limitations, these ratios are not all calculated using data for the same year, though most observations represent the period 1986-1988. ${ }^{18}$ In the empirical work that follows, the variables that influence $R \& D$ demand are interacted with these country-level measures of R\&D intensity. This procedure represents a simple, if rather unsubtle, adjustment for heterogeneity among countries in the extent to which their firms undertake R\&D. Local R\&D

\footnotetext{
${ }^{17} \mathrm{At}$ a first pass, this association is suggestive of a complementary relationship between local R\&D and imported technology, since affiliates of multinational firms headquartered in R\&D-intensive countries probably face lower real costs of importing technology than do affiliates of firms from other countries. But differences in the technological intensities of parent firms also reflect heterogeneity between affiliates that can invalidate such an inference.

${ }^{18} \mathrm{R} \& \mathrm{D} / \mathrm{GNP}$ ratios change little from year to year, as evidenced by the time-series data on France, Germany, Japan, the United Kingdom, and the United States presented in Table 2. These economies, which are among the most R\&D-intensive in the world, exhibit only gradual movements in R\&D intensity relative to each other. This pattern suggests that time-invariant cross-sectional differences in R\&D intensity are likely to be much more important than any differences created by the asynchronous nature of the data reported by the National Science Foundation.
} 
intensity can have an important impact on the demand for imported technology as well, so the R\&D intensity variable appears in the royalty equations. Since R\&D intensity is likely to have less direct an impact on royalties than it does on $R \& D$ expenditures, the $R \& D$ intensity variable enters the royalty equations independently of the other explanatory variables.

Information on tax systems and tax rates is reported by Price Waterhouse (various issues). In the empirical work that follows, firms are assumed to face effective tax rates on their technology-related activities equal to statutory corporate tax rates in host countries. Tables 3 and 4 report means and standard deviations of the variables used in the empirical work.

\section{Foreign Afriliates of American Multinational Corporations,}

The model described by equations (1)-(6) carries the implication that technologyrelated royalty payments and $R \& D$ spending levels should respond to local tax rates. Specifically, the model predicts that higher withholding taxes on royalties will reduce royalty payments both by discouraging technology transfers, and by reducing the ratio of reported royalties to the values of technologies transferred.

The regressions reported in Table 5 test these implications on the data that describe the behavior of the foreign affiliates of American multinational corporations for the year 1989. Table 5 presents estimates of the coefficients that correspond to the implied specification of the royalty demand equation that emerges from (3) and (5). The dependent variable is a ratio, the numerator of which is royalties paid by the foreign affiliates of U.S. firms to their parent companies, and the denominator of which is total sales by the affiliates. ${ }^{19}$ Data represent country aggregates.

${ }^{19}$ The equations reported in Table 5 were all re-run using total royalties paid in place of royalties paid to U.S. parents, with very similar results. (And not surprisingly, since, as Table 1 indicates, 80 percent of all royalties paid by the foreign affiliates of American firms go to the parent companies of the affiliates paying the royalties.) The regressions reported in Table 5 use royalties paid to parent companies because only for those royalties is it clear at what rate the royalties will be taxed. 
The estimates reported in column 1 of Table 5 imply that royalty payments respond negatively to royalty tax rates and are close to unaffected by statutory tax rates. The coefficients indicate that, at a statutory tax rate of 35 percent, a 10 percent reduction in the withholding tax rate on royalties stimulates additional royalty payments equal to 0.1 percent of sales. The implied elasticity of royalty payments with respect to the royalty tax rate, calculated using these estimates and mean values of the variables as reported in Table 2 , is approximately $-0.4 .^{\circ}$ If sales are unaffected by changes in royalty tax rates, then this figure implies that doubling the royalty tax rate reduces royalties by 40 percent, a sizable fraction.

Since sales may respond to tax rate changes, this calculation may understate the responsiveness of royalties, but nevertheless strongly suggests that the true elasticity lies between zero and -1 . It is, however, important to note that the aggregate nature of the data may introduce considerable measurement error that biases the estimated coefficient toward zero. The sign of any bias introduced by omitted variables is ambiguous, though the magnitude could be large.

The results presented in column 2 of Table 5 indicate that royalties also respond significantly to differences between royalty withholding tax rates and statutory tax rates. As predicted, the local R\&D/GNP ratio is positively correlated with royalty payments. Alternative specifications reported in columns 3-5 of Table 5 yield similar conclusions: high tax rates on royalties are associated with lower ratios of royalty payments to total sales.

The specifications used to obtain the results described in Table 5 were changed in a number of ways, in every case generating similar results. One specification issue concerns the appropriate choice of denominator for the dependent variable. Specifications in which labor compensation replaces sales as the denominator of the dependent variable yield results that are almost

\footnotetext{
${ }^{20}$ Exercises such as this one are fraught with dangers, since variables may exhibit considerable differences between their conditional and unconditional means. The calculation in the text is meant only to be illustrative.
} 
identical to those reported in Table 5. Due to the somewhat heterogeneous nature of royalties, it seems most appropriate to scale this variable by sales. In the regressions reported in Tables 6 and 9 , the dependent variables that represent $R \& D$ expenditures are scaled by labor compensation in manufacturing for somewhat different reasons. Manufacturing affiliates account for approximately 90 percent of the R\&D activity of foreign-owned affiliates in the U.S. and of the foreign aftiliates of U.S. firms. Labor expenditures share with R\&D expenditures the feature of immediate deductibility for tax purposes, ${ }^{21}$ and are more reasonably thought of as the product of firm choices than are sales, which may be functions of R\&D. All of the R\&D demand equations in reported in Tables 6 and 9 were re-run scaling the dependent variable by labor expenditures, with results that are very similar to those reported in the tables.

\section{A First Approach to Estimating the Impact of Taxes on $R \& D$}

The results reported in Table 5 indicate that royalty payments by the foreign affiliates of U.S. multinational firms respond to tax rates in the predicted manner. The model described in equations (1)-(6) does not, however, carry a prediction about the sign of the effect of tax rates on $R \& D$ expenditure levels, and the object of the regressions reported in Tables 6 and 7 is to measure the sign of any effect that may be present. The regressions reported in Tables 6 and 7 address this measurement problem using very different methodologies, though, as it happens, the results point to conclusions that are quite similar.

Table 6 presents regressions that estimate of the impact of the tax treatment of

${ }^{21}$ Of course, some countries (including the United States) offer tax credits and other inducements to firms that perform R\&D (and in some cases to firms that hire labor). A brief survey of country practices indicates, however, that sizable R\&D subsidies are rare [for example, see Hall (1993) for an analysis of the magnitude of the marginal subsidy provided R\&D in the United States by the Research and Experimentation Tax Credit], and that the primary subsidy comes from the immediate deductibility of $R \& D$ expenses that almost all industrialized countries provide. 
royalties on the R\&D-intensities of foreign affiliates of U.S. firms, using specifications drawn from the model described in equations (1)-(6). The dependent variable is the ratio of $R \& D$ expenditures in 1989 to manufacturing labor compensation in 1989 . The results in the table are strongly suggestive of an important impact of royalty taxes on R\&D activity, but not all of the estimated coefficients in the table are significant. The strongest and most parsimonious specification is presented in column 2 of Table 6, and here the estimated coefficients suggest that an unfavorable tax climate for royalties is associated with greater R\&D activity. Imported technology and local R\&D appear to be substitutes.

Columns 3-5 of Table 6 report the results of alternative specifications of the model. Two aspects of these results are noteworthy. The first is that the estimated coefficients on the variable $\left[1 /\left(1-\tau^{*}\right) \cdot(\mathrm{R} \& \mathrm{D} / \mathrm{GNP})\right]$ are always insignificant. This variable appears as one part of the first term on the right side of (5), and the estimated coefficient captures the effect of $c$, the cost of developing technology at home to transfer to affiliates abroad. The insignificance of the estimated coefficient implies either that firms transfer nonrival technologies to their affiliates, so $c=0$, or that the estimating methodology is not powerful enough to identify an important effect. The second noteworthy aspect of the results is that the specifications that include quadratic tax terms generate insignificant results. These results may reflect the limited ability of the estimators to distinguish the effects of collinear variables in a small sample.

Using the coefficient estimate from the equation presented in column 1 of Table 6 , the implied elasticity of R\&D activity with respect to the withholding tax rate on royalties (evaluating all variables at their sample means) is approximately 0.16 . This figure is smaller than the implied royalty elasticity calculated from Table 5, which is reassuring, since own-price elasticities are usually stronger than cross-price elasticities. This estimated elasticity suggests that local R\&D is a mild substitute for imported technology, but it is helpful to consider additional evidence before drawing any conclusions. 


\section{A Second Approach to Estimating the Impact of Taxes on R\&D}

One of the difficulties that arise in estimating the impact of royalty tax rates on local $R \& D$ levels is that many omitted variables influence $R \& D$ spending. It is possible that these variables are correlated with royalty withholding tax rates in a way that biases the estimated tax rate coefficients, and generates a misleading conclusion concerning the substitutability of R\&D for imported technology. The regressions reported in Table 6 control for local technological environments simply by interacting the tax variables with the (R\&D/GNP) measure.

An alternative approach is to use available information that distinguishes the R\&D activity of foreign aftiliates of American firms for their own purposes from R\&D activity that they undertake on behalf of others. Both types of R\&D activity are likely to be influenced by local economic and technological conditions. It is, however, possible that the latter type of contract-style $R \& D$ performed for others is generally unaffected by the availability of technology imports from parent firms. If not, then R\&D performed for others serves as a control group with which to compare R\&D performed by affiliates for their own purposes. Under the hypothesis that R\&D performed for others is unaffected by technology imports, the fraction of an affiliate's total R\&D activity undertaken for itself is a positive function of royalty taxes if local R\&D and imported technology are substitutes, and a negative function of royalty taxes if local R\&D and imported technology are complements.

There are 38 countries in the sample for which the BEA data distinguish R\&D performed by affiliates for themselves from R\&D performed by affiliates for others. Table 7 presents estimated coefficients from regressions in which the dependent variable is the ratio of R\&D performed by affiliates for themselves to total R\&D by affiliates. The results once again suggest that local R\&D is a substitute for imported technology. In the regression reported in column 1 of Table 7, the estimated coefficient on royalty withholding tax rates is positive and significant; the same is true of 
the coefficient on the difference between withholding and statutory tax rates reported in column 2 . The coefficient estimates reported in column 2 indicate that a 10 percent change in the difference between foreign withholding and statutory tax rates (normalized by one minus the foreign statutory tax rate) is associated with a 2.6 percent change in the intensity of R\&D activity by affiliates for themseives.

Columns 3-5 of Table 7 report the results of alternative specifications of the R\&D demand equation. The coefficient estimates from these specifications are consistent with those reported in columns 1-2, and are also consistent with the results reported in Table 6. In particular, the estimated coefficient of the variable $1 /\left(1-\tau^{*}\right)$ is again insignificant. The estimates reported in column 1 of Table imply that the elasticity of R\&D spending with respect to royalty withholding taxes (evaluating all variables at their sample means) is approximately 0.11 , which resembles the elasticity calculated from estimates reported in Table 6.

The regressions reported in Tables 6 and 7 offer consistent evidence that the aggregate behavior of the foreign affiliates of American multinational firms exhibits substitution of local R\&D for imported technology. It is important to note, however, that there can be more than one interpretation of this pattern at the level of individual firms. One possibility is that tax differences influence the behavior of firms located in different countries. A second possibility is that tax differences encourage specific firms to locate in certain countries and not in others, without influencing the R\&D intensities of individual firms. ${ }^{2}$ A third, and perhaps the most likely, possibility represents some combination of the first two. The use of aggregate data makes it impossible to use the observed pattern of behavior to distinguish these explanations, though, for many purposes, it many not be necessary to distinguish them.

${ }^{2}$ Lipsey, Blomstrom, and Kravis (1990) examine the impact of host-country characteristics on the attributes - particularly R\&D intensitites - of multinational firms choosing to locate within the country. They do not, however, consider the impact of tax policies. 


\section{Foreign-Owned Affiliates in the United States}

The behavior of foreign-owned affiliates in the United States offers additional evidence on the responsiveness of $R \& D$ activity to royalty tax rates. This evidence must, however, be interpreted with caution, owing to hetergeneous circumstances of foreign firms that invest in the United States and the small sample size of 27 foreign countries for which sufficient data are available.

Home-country tax treatments of foreign multinational firms that invest in the United States differ according to ind ividual circumstances and national law. There are two dimensions along which the variation between investors is most important. The home governments of some foreign investors tax the worldwide incomes of their residents while granting credits for foreign taxes paid, while other governments exempt all foreign-source income from tax..$^{23}$ A second dimension along which tax systems differ concerns the degree of integration of personal and corporate taxes. For some countries, their corporation taxes largely represent advanced withholding taxes against personal tax liabilities.

The specification of royalty equations corresponding to the system described by (1)-(6) is somewhat different in the case of foreign investors in the United States than it is in the regressions reported in Table 5. To start, the tax rate $r^{*}$ is the United States tax rate, which is the same for all foreign investors. The value of $c$, the cost of producing technology for export, need not be similar for different foreign investors, and is captured in the estmating equations by the inclusion of $\mathrm{R} \& \mathrm{D} / \mathrm{GNP}$ as an explanatory variable. And there may be important differences between the incentives facing investors from foreign tax credit countries and investors from countries that do not grant foreign tax credits.

Table 8 presents estimates of the determinants of royalty payments by foreign-owned

OOf course, this dichotomous breakdown greatly oversimplifies the many distinctions and subtleties that foreign tax systems exhibit. 
affiliates in the United States in 1987. The coefficient on the withholding tax rate in the regression presented in the column 2 of Table 8 implies that raising the tax rate by 10 percent reduces the royalty/sales ratio by 0.74 percent. The estimated coefficient lies just at the margin of statistical significance. To understand its magnitude in a different way, the implied elasticity of royalties/sales, evaluating all variables at their population means, is approximately -0.12 . If sales are unaffected by changes in royalty tax rates, then this figure implies that doubling the royalty tax rate reduces royalties by 12 percent.

Column 3 of Table 8 presents the same regression in which the withholding tax rate is now transformed to be zero for all investors from foreign tax credit countries. The results are very similar to those reported in column 2. Columns 4 and 5 report results of regressions in which squares of the withholding tax rates are introduced; the coefficient estimates are insignificant, reflecting the multicollinearity of the two tax rate variables and the limited amount of variation in a sample of this size.

Table 9 presents estimated coefficients from regressions that investigate the correlation between the R\&D intensity of foreign-owned affiliates in the United States and the tax variables that influence the cost of imported technology. One striking feature of all of the regressions presented in Table 9 is the strong correlation between the R\&D-intensity of foreign-owned affiliates in the United States and the R\&D-intensity of the countries in which their parent firms are located. Column 2 presents the simplest specification that includes tax rate variables; the estimated coefficient on the interaction between the withholding tax rate and home-country R\&D intensity is positive and significant. The implied elasticity of R\&D with respect to the cost of imported technology (evaluated at sample means) is approximately 0.3 . This is a very sizable elasticity, particularly in view of the smaller own-price elasticity of royalties implied by the estimates reported in Table 8. Furthermore, the reponsiveness of royalties to withholding tax rates reflects changes in reporting behavior in 
addition to changes in amounts of technology transferred. The elasticity implies that, in the absence of an effect arising through the scale of operations, doubling the withholding tax rate raises R\&D expenditures by 30 percent. This estimated response magnitude is very large, and may reflect the imprecision of estimates drawn from so small a sample. Nevertheless, it is striking that the pattern of substitutability between R\&D and imported technology appears for foreign investors in the United States as well as American investors in other countries. ${ }^{24}$

Column 3 of Table 9 presents estimates from the specification in which the withholding tax rate is interacted with a variable that equals zero if the investor's parent company is located in a foreign tax credit country, and equals one otherwise. The results are qualitatively very similar to those presented in column 2, with the difference that the estimated R\&D appears in this specification to be even more responsive to withholding tax rates. Columns 4 and 5 present regression results for specifications that include quadratic withholding tax rate terms, which again exhibit symptoms of multicollinearity.

Evidence on the behavior of foreign-owned affiliates in the United States suggests conclusions that are very similar to those that emerge from the behavior of the foreign affiliates of American corporations. Foreign investors in the United States pay fewer royalties, and use more R\&D-intensive operations, when facing higher tax rates on royalties paid to their home countries. The restricted size of the sample of investing foreign countries makes statistical inference difficult, but the estimated coefficients indicate a responsiveness that is somewhat greater than that for the foreign affiliates of American corporations.

\footnotetext{
${ }^{24}$ Unfortunately, BEA does not require foreign-owned firms in the United States to distinguish the R\&D they perform for their own use from R\&D that they perform for others, so it is not possible to estimate equations of the type reported in Table 7 for foreign investors in the United States.
} 


\section{Conclusion.}

This paper uses information on the behavior of the foreign affiliates of U.S. firms and toreign-owned aftiliates in the United States to estimate the relationship between technology imports and local R\&D. The idea is to use the tax treatment of royalty payments to identify the degree of substitutability between these sources of technology. Evidence from the actions of American and foreign firms indicates that R\&D expenditures respond to local tax rates, and that technology imports and local R\&D are substitutes. The substitutability of these two sources of technology carries numerous implications for the impact of tax policy on R\&D activity, particularly when contrasted with the complementarity that is sometimes thought to characterize their relationship. 


\section{References}

Blomstrom, Magnus (1991), "Host Country Benefits of Foreign Investment," NBER Working Paper No. 3615 .

Blomstrom, Magnus and Ari Kokko (1993), "Policies to Encourage Inflows of Technology through Foreign Multinationals," NBER Working Paper No. 4289.

Davidson, W.H. and Donald G. McFetridge (1984), "International Technology Transactions and the Theory of the Firm," Journal of Industrial Economics, 32, 253-264.

Dixit, Avinash (1988), "International R\&D Competition and Policy," in A. Michael Spence and Heather A. Hazard eds. International Competitiveness (Cambridge: Ballinger), 149-171.

Ethier, Wilfred J. and James R. Markusen (1991), "Multinational Firms, Technology Diffusion and Trade," NBER Working Paper No. 3825.

Germidis, Dimitri (1977) ed., Transfer of Technology by Multinational Corporations (Paris: Organization for Economic Cooperation and Development).

Griliches, Zvi (1991), "The Search for R\&D Spillovers," NBER Working Paper No. 3768.

Grubert, Harry and John Mutti (1991), "Taxes, Tariffs, and Transfer Pricing in Multinational Corporate Decisionmaking," Review of Economics and Statistics, 73, 285-293.

Hall, Bronwyn H. (1993), "R\&D Tax Policy During the 1980s: Success or Failure?" in James M. Poterba ed. Tax Policy and the Economy, Vol. 7 (Cambridge: MIT Press), 1-35.

Harris, David, Randall Morck, Joel Slemrod, and Bernard Yeung (1993), "Income Shifting in U.S. Multinational Corporations," in Alberto Giovannini, R. Glenn Hubbard, and Joel Slemrod eds. Studies in International Taxation (Chicago: University of Chicago Press), 277-302.

Hartman, David G. (1985), "Tax Policy and Foreign Direct Investment," Journal of Public Economics, 26, 107-121.

Hines, James R., Jr. (1991), "The Flight Paths of Migratory Corporations, "Journal of Accounting, Auditing and Finance, 6, 447-479.

Hines, James R., Jr. (1993), "On the Sensitivity of R\&D to Delicate Tax Changes: The Behavior of US Multinationals in the 1980s," in Alberto Giovannini, R. Glenn Hubbard, and Joel Slemrod eds. Studies in International Taxation (Chicago: University of Chicago Press), 149-187.

Hines, James R., Jr. (1994a), "No Place Like Home: Tax Incentives and the Location of R\&D by American Multinationals," in James M. Poterba, ed. Tax Policy and the Economy, Volume 8 (Cambridge, MA: MIT Press), 65-104.

Hines, James R., Jr. (1994b), "Credit and Deferral as International Investment Incentives," Journal of Public Economics, 55, 323-347. 
Hines, James R., Jr. and R. Glenn Hubbard (1990), "Coming Home to America: Dividend Repatriations by US Multinationals, " in Assaf Razin and Joel Slemrod eds. Taxation in the Global Economy (Chicago: University of Chicago Press), 161-200.

Hines, James R., Jr. and Eric M. Rice (1994), "Fiscal Paradise: Foreign Tax Havens and American Business," Quarterly Journal of Economics, 109, 149-182.

Kopits, George F. (1976), "Intra-Firm Royalties Crossing Frontiers and Transfer-Pricing Behaviour," Economic Journal, 86, 791-805.

Lawlor, William R., ed. (1985), Cross-Border Transactions between Related Companies: A Summary of Tax Rules (Deventer, the Netherlands: Kluwer).

Lipsey, Robert E., Magnus Blomstrom, and Irving B. Kravis (1990), "R\&D by Multinational Firms and Host Country Exports," in Rober E. Evenson and Gustav Ranis eds. Science and Technology: Lessons for Development Policy (Boulder, CO: Westview Press), 271-300.

Mansfield, Edwin and Anthony Romeo (1980), "Technology Transfer to Overseas Subsidiaries by U.S.-Based Firms," Quarterly Journal of Economics, 95, 737-750.

Manstield, Edwin, David Teece, and Anthony Romeo (1979), "Overseas Research and Development by U.S.-Based Firms," Economica, 46, 187-196.

Nadiri, M. Ishaq (1993), "Innovations and Technological Spillovers," NBER Working Paper No. 4423.

National Science Foundation (1991), International Science and Technology Data Update: 1991, NSF 91-309 (Washington, D.C.: National Science Foundation),

National Science Foundation (1993), Selected Data on Research and Development in Industry: 1991 (Washington, D.C.: National Science Foundation).

Price Waterhouse (various issues), Corporate Taxes - A Worldwide Summary (New York: Price Waterhouse).

Reinganum, Jennifer F. (1989), "The Timing of Innovation: Research, Development, and Diffusion," in Richard Schmalensee and Robert D. Willig eds. Handbook of Industrial Organization, Vol. 1 (Amsterdam: North-Holland).

Scholes, Myron S. and Mark A. Wolfson (1992), Taxes and Business Strategy: A Planning Approach (Englewood Cliffs, NJ: Pretice Hall).

Teece, David J. (1976), The Multinational Corporation and the Resource Cost of International Technology Transfer (Cambridge: Ballinger).

United States Congress, Joint Committee on Taxation (1981), General Explanation of the Economic Recovery Tax Act of 1981 (Washington, D.C.: US Government Printing Office). 
United States Department of Commerce, Bureau of Economic Analysis, Foreign Direct Investment in the United States, various issues.

United States Department of Commerce, Bureau of Economic Analysis (1985), U.S. Direct Investment Abroad: 1982 Benchmark Survey Data (Washington, D.C.: US Government Printing Office).

United States Department of Commerce, Bureau of Economic Analysis (1990), Foreign Direct Investment in the United States: 1987 Benchmark Survey, Final Results (Washington, D.C.: US Government Printing Office).

United States Department of Commerce, Bureau of Economic Analysis (1992), U.S. Direct Investment Abroad: 1989 Benchmark Survey, Final Results (Washington, D.C.: US Government Printing Office).

Wang, Jian-Ye and Magnus Blomstrom (1992), "Foreign Investment and Technology Transfer: A Simple Model, "European Economic Review, 36, 137-155.

Zejan, Mario C. (1990), "R\&D Activities in Affiliates of Swedish Multinational Enterprises," Scandinavian Journal of Economics, 92, 487-500. 
Figure 1

R\&D by Foreign Firms in the US, and by American Firms Abraad, 1977-1990

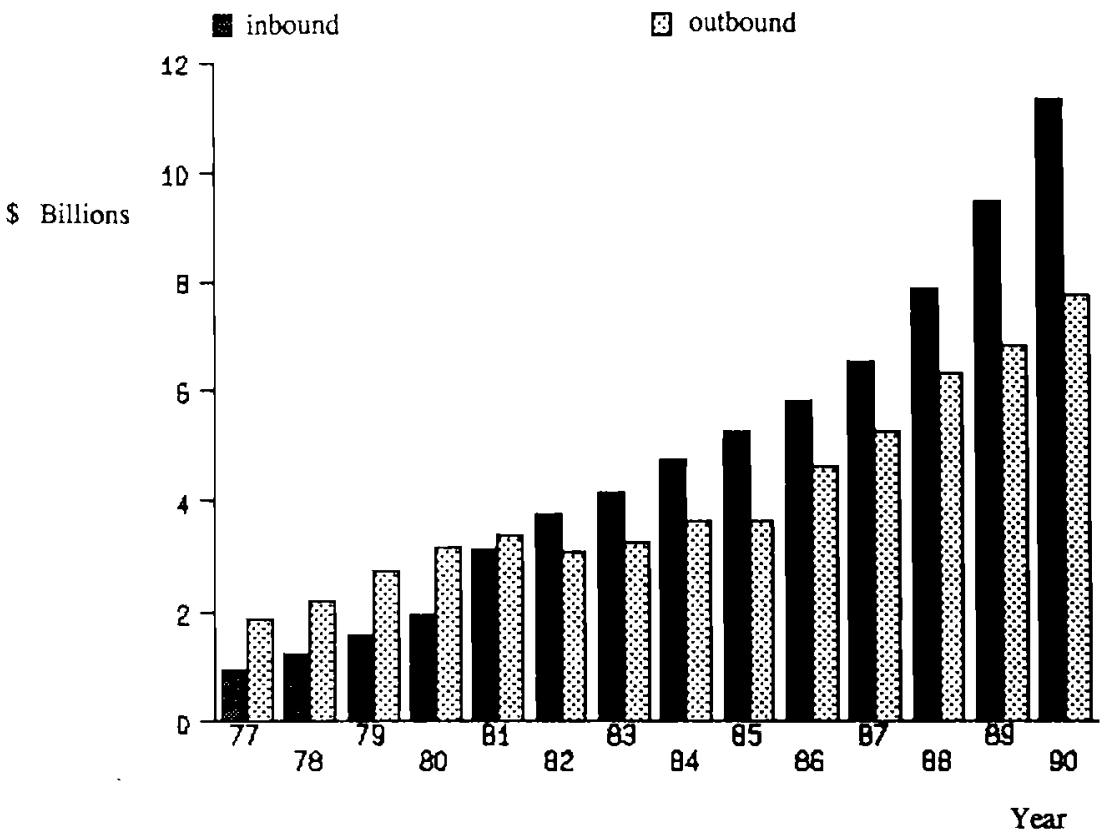

Note: The vertical scale measures billions of current dollars of annual R\&D expenditures. Darkly shaded bars represent total R\&D expenditures of foreign-owned firms in the United States. Lightly shaded bars represent total R\&D expenditures of foreign affiliates of American firms.

Sources: United States Department of Commerce, Bureau of Economic Analysis, Foreign Direct Investment in the United States, various issues, and National Science Foundation (1993). 
Table 1

R\&D and Royalty Activity of Foreign Affiliates of US Multinationals

Year

1982

1989

$R \& D$ expenditures, total

$\begin{array}{rr}\$ 3,851 & \$ 7,922 \\ 3,073 & 6,307 \\ 778 & 1,615\end{array}$

$R \& D$ by affiliate for itself

$R \& D$ by affiliate for others

435

1,461

Royalty receipts, total

36

54

Receipts from US parents

193

656

Receipts from other foreign affiliates

26

97

Receipts from unaffiliated foreigners

180

654

Royalty payments, total

4,308

12,472

Payments to US parents

Payments to other foreign affiliates

Payments to unaffiliated Americans

Payments to unaffiliated foreigners

$\begin{array}{rr}3,663 & 9,839 \\ 354 & 1,488 \\ 102 & 660 \\ 189 & 485\end{array}$

Note: Dollar amounts are millions of current dollars. Data cover majority-owned foreign affiliates of US multinational firms.

Source: US Department of Commerce, Bureau of Economic Analysis (1985, 1992). 
Table 2

R\&D Expenditure as a Percentage of GNP, 1961-1989

\begin{tabular}{|c|c|c|c|c|c|}
\hline & France & $\begin{array}{l}\text { West } \\
\text { Germany }\end{array}$ & Japan & $\begin{array}{l}\text { United } \\
\text { Kingdom }\end{array}$ & $\begin{array}{l}\text { United } \\
\text { States }\end{array}$ \\
\hline 1961 & 1.4 & - & 1.4 & 2.5 & 2.7 \\
\hline 1962 & 1.5 & 1.2 & 1.5 & - & 2.7 \\
\hline 1963 & 1.6 & 1.4 & 1.5 & - & 2.8 \\
\hline 1964 & 1.8 & 1.6 & 1.5 & 2.3 & 2.9 \\
\hline 1965 & 2.0 & 1.7 & 1.6 & - & 2.8 \\
\hline 1966 & 2.1 & 1.8 & 1.5 & 2.3 & 2.8 \\
\hline 1967 & 2.2 & 2.0 & 1.6 & 2.3 & 2.8 \\
\hline 1968 & 2.1 & 2.0 & 1.7 & 2.2 & 2.8 \\
\hline 1969 & 2.0 & 1.8 & 1.7 & 2.3 & 2.7 \\
\hline 1970 & 1.9 & 2.1 & 1.9 & - & 2.6 \\
\hline 1971 & 1.9 & 2.2 & 1.9 & - & 2.4 \\
\hline 1972 & 1.9 & 2.2 & 1.9 & 2.1 & 2.4 \\
\hline 1973 & 1.8 & 2.1 & 2.0 & - & 2.3 \\
\hline 1974 & 1.8 & 2.1 & 2.0 & - & 2.2 \\
\hline 1975 & 1.8 & 2.2 & 2.0 & 2.1 & 2.2 \\
\hline 1976 & 1.8 & 2.1 & 2.0 & - & 2.2 \\
\hline 1977 & 1.8 & 2.1 & 2.0 & - & 2.2 \\
\hline 1978 & 1.8 & 2.2 & 2.0 & 2.2 & 2.1 \\
\hline 1979 & 1.8 & 2.4 & 2.1 & - & 2.2 \\
\hline 1980 & $\begin{array}{l}1.0 \\
1.8\end{array}$ & 2.4 & 2.2 & - & 2.3 \\
\hline 1981 & 2.0 & 2.5 & 2.3 & 2.4 & 2.4 \\
\hline 1982 & 2.1 & 2.6 & 2.4 & - & 2.5 \\
\hline 1983 & 2.1 & 2.6 & 2.6 & 2.2 & 2.6 \\
\hline 1984 & 2.2 & 2.6 & 2.6 & - & 2.7 \\
\hline 1985 & 2.3 & 2.8 & 2.8 & 2.3 & 2.8 \\
\hline 1986 & 2.3 & 2.8 & 2.8 & 2.4 & 2.8 \\
\hline 1987 & 2.3 & 2.9 & 2.8 & 2.3 & 2.8 \\
\hline 1988 & 2.3 & 2.9 & 2.9 & 2.2 & 2.7 \\
\hline 1989 & 2.3 & 2.9 & 3.0 & 2.0 & 2.7 \\
\hline
\end{tabular}

Note: French data are based on Gross Domestic Product (GDP); consequently, percentages may be slightly overstated compared to GNP. Omissions (-) indicate that R \& D data are unavailable.

Source: National Science Board (1991). 
Table 3

Variable Means and Standard Deviations, Foreign Afriliates of US Corporations, 1989

\begin{tabular}{|c|c|c|c|}
\hline Variable & Mean & Standard Deviation & No. Obs. \\
\hline & & $\cdot$ & \\
\hline Parent Royalties/Sales & 0.00774 & 0.00693 & 41 \\
\hline R\&D/Labor Compensation & 0.05370 & 0.06317 & 43 \\
\hline R\&D for Affiliate/Total R\&D & 0.89466 & 0.16576 & 38 \\
\hline $\mathrm{R} \& \mathrm{D} / \mathrm{GDP}$ & 0.01080 & 0.00878 & 41 \\
\hline$w^{*} /\left(1-\tau^{*}\right)$ & 0.42149 & 0.54876 & 41 \\
\hline$\tau^{*} /\left(1-\tau^{*}\right)$ & 0.65270 & 0.29224 & 41 \\
\hline$\left(\mathrm{w}^{*}-\tau^{*}\right) /\left(1-\tau^{*}\right)$ & -0.23121 & 0.46387 & 41 \\
\hline$\left[\left(\mathrm{w}^{*}-\tau^{*}\right) /\left(1-\tau^{*}\right)\right]^{2}$ & 0.26339 & 0.27492 & 41 \\
\hline $1 /\left(1-\tau^{*}\right)$ & 1.65270 & 0.29224 & 41 \\
\hline$w^{*}$ & 0.20784 & 0.25274 & 38 \\
\hline$\tau^{*}$ & 0.37666 & 0.09167 & 38 \\
\hline$\left[\mathrm{w}^{*} /\left(1-\tau^{*}\right)\right](\mathrm{R} \& \mathrm{D} / \mathrm{GNP})$ & 0.00263 & 0.00446 & 43 \\
\hline$\left[\tau^{*} /\left(1-\tau^{*}\right)\right](\mathrm{R} \& \mathrm{D} / \mathrm{GNP})$ & 0.00737 & 0.00797 & 43 \\
\hline$\left[\left(\mathrm{w}^{*}-\tau^{*}\right) /\left(1-\tau^{*}\right)\right](\mathrm{R} \& \mathrm{D} / \mathrm{GNP})$ & -0.00475 & 0.00752 & 43 \\
\hline$\left[\left(w^{*}-\tau^{*}\right) /\left(1-\tau^{*}\right)\right]^{2}(\mathrm{R} \& D / G N P)$ & 0.00388 & 0.00641 & 43 \\
\hline$\left[1 /\left(1-\tau^{*}\right)\right](\mathrm{R} \& \mathrm{D} / \mathrm{GNP})$ & 0.01793 & 0.01602 & 43 \\
\hline
\end{tabular}

Note: The regressions reported in Tables 5-7 use these variables. The first three represent countrylevel aggregate activities of foreign affiliates of U.S. corporations in 1989, as reported in U.S. Department of Commerce, Bureau of Economic Analysis (1992). The variable (R\&D/GNP) represents country R\&D/GNP ratios reported by the National Science Foundation (1991). The variable $\tau^{*}$ represents local statutory corporate tax rates, and $\mathrm{w}^{*}$ represents withholding tax rates imposed by foreign countries on royalty payments to the United States. Observations are countrylevel aggregates of the behavior of all U.S.-owned affiliates. 
Table 4

Variable Means and Standard Deviations, Foreign-Owned Affiliates in the United States, -1987

\begin{tabular}{|c|c|c|c|}
\hline Variable & Mean & Standard Deviation & No. Obs. \\
\hline Royalties/Sales & 0.00759 & 0.00936 & 27 \\
\hline R\&D/Labor Compensation & 0.08749 & 0.13590 & 27 \\
\hline R\&D/GNP & 0.01511 & 0.00932 & 27 \\
\hline$w$ & 0.12037 & 0.12805 & 27 \\
\hline$w(1-F T C)$ & 0.06481 & 0.11752 & 27 \\
\hline$w^{2}$ & 0.03028 & 0.03998 & 27 \\
\hline $\mathrm{w}^{2}(1-\mathrm{FTC})$ & 0.01750 & 0.03532 & 27 \\
\hline$w(R \& D / G N P)$ & 0.00120 & 0.00190 & 27 \\
\hline$w(1-F T C)(R \& D / G N P)$ & 0.00068 & 0.00181 & 27 \\
\hline $\mathrm{w}^{2}(\mathrm{R} \& \mathrm{D} / \mathrm{GNP})$ & 0.00028 & 0.00056 & 27 \\
\hline $\mathrm{w}^{2}(1-\mathrm{FTC})(\mathrm{R} \& \mathrm{D} / \mathrm{GNP})$ & 0.00017 & 0.00054 & 27 \\
\hline
\end{tabular}

Note: The regressions reported in Tables 8 and 9 use these variables. The first two variables represent country-level aggregate activities of foreign-owned affiliates in the United States in 1987, as reported in U.S. Department of Commerce, Bureau of Economic Analysis (1990). The variable (R\&D/GNP) represents country R\&D/GNP ratios reported by the National Science Foundation (1991). The variable w represents the withholding tax rate imposed by the United States on royalty payments from the United States. The variable FTC equals unity if an investor's home country taxes worldwide income and grants foreign tax credits to its residents, and equals zero otherwise.

Observations are country-level aggregates of the behavior of all U.S.-owned affiliates. 
Table 5

Royalty Tax Rates and Royalty Payments by Foreign Affiliates of U.S. Corporations, 1989

Dependent Variable: (Royalties Paid to U.S. Parents/Total Sales), U.S.-Owned Affiliates

\begin{tabular}{|c|c|c|c|c|c|}
\hline Constant & $\begin{array}{c}0.0060 \\
(0.0027)\end{array}$ & $\begin{array}{c}0.0014 \\
(0.0014)\end{array}$ & $\begin{array}{c}0.0142 \\
(0.0067)\end{array}$ & $\begin{array}{c}0.0016 \\
(0.0015)\end{array}$ & $\begin{array}{c}0.0176 \\
(0.0078)\end{array}$ \\
\hline$R \& D / G N P$ & $\begin{array}{c}0.4310 \\
(0.1201)\end{array}$ & $\begin{array}{c}0.4023 \\
(0.1215)\end{array}$ & $\begin{array}{c}0.4310 \\
(0.1201)\end{array}$ & $\begin{array}{c}0.4310 \\
(0.1282)\end{array}$ & $\begin{array}{c}0.4002 \\
(0.1240)\end{array}$ \\
\hline$\left[w^{*} /\left(1-\tau^{*}\right)\right]$ & $\begin{array}{l}-0.0068 \\
(0.0027)\end{array}$ & & & & \\
\hline$\left[r^{*} /\left(1-\tau^{*}\right)\right]$ & $\begin{array}{l}-0.0013 \\
(0.0042)\end{array}$ & & & & \\
\hline$\left[\left(\mathrm{w}^{*}-\mathrm{r}^{*}\right) /\left(1-\tau^{*}\right)\right]$ & & $\begin{array}{l}-0.0061 \\
(0.0025)\end{array}$ & $\begin{array}{l}-0.0068 \\
(0.0027)\end{array}$ & $\begin{array}{c}-0.0063 \\
(0.0025)\end{array}$ & $\begin{array}{c}-0.0066 \\
(0.0027)\end{array}$ \\
\hline$\left[\left(w^{*}-r^{*}\right) /\left(1-\tau^{*}\right)\right]^{2}$ & & & & $\begin{array}{l}-0.0027 \\
(0.0037)\end{array}$ & $\begin{array}{c}0.0039 \\
(0.0046)\end{array}$ \\
\hline$\left[1 /\left(1-\tau^{*}\right)\right]$ & & & $\begin{array}{l}-0.0082 \\
(0.0042)\end{array}$ & & $\begin{array}{l}-0.0107 \\
(0.0052)\end{array}$ \\
\hline$\hat{\partial}$ & $\begin{array}{c}0.0053 \\
(0.0007)\end{array}$ & $\begin{array}{c}0.0055 \\
(0.0007)\end{array}$ & $\begin{array}{c}0.0053 \\
(0.0007)\end{array}$ & $\begin{array}{c}0.0055 \\
(0.0007)\end{array}$ & $\begin{array}{c}0.0052 \\
(0.0006)\end{array}$ \\
\hline $\log \mathrm{L}$ & 125.0988 & 122.8083 & 125.0988 & 123,0681 & 125.4541 \\
\hline $\mathrm{n}$ & 41 & 41 & 41 & 41 & 41 \\
\hline
\end{tabular}

Note: The columns report coefficients from Tobit regressions in which the dependent variable is the ratio of royalties paid by foreign affiliates of U,S. corporations to their parent companies to the affiliates' total sales. The variable (R\&D/GNP) represents country R\&D/GNP ratios reported by the National Science Foundation (1991). The variable $\tau^{*}$ represents local statutory corporate tax rates, and $w^{*}$ represents withholding tax rates imposed by foreign countries on royalty payments to the United States. Observations are country-level aggregates of the behavior of all U.S.-owned affiliates. Standard errors are in parentheses. 
Table 6

Local Tax Rates and R\&D Intensities of Foreign Affiliates of U.S. Corporations, 1989

Dependent Variable: Local (R\&D/Manufacturing Labor Compensation), U.S.-Owned Affiliates

\begin{tabular}{|c|c|c|c|c|c|}
\hline Constant & $\begin{array}{l}-0.0260 \\
(0.0146)\end{array}$ & $\begin{array}{l}-0.0274 \\
(0.0150)\end{array}$ & $\begin{array}{l}-0.0260 \\
(0.0146)\end{array}$ & $\begin{array}{l}-0.0208 \\
(0.0146)\end{array}$ & $\begin{array}{l}-0.0209 \\
(0.0147)\end{array}$ \\
\hline R\&D/GDP & $\begin{array}{l}10.0631 \\
(2.0237)\end{array}$ & $\begin{array}{c}8.8330 \\
(1.8161)\end{array}$ & $\begin{array}{l}12.7071 \\
(3.4801)\end{array}$ & $\begin{array}{c}8.0861 \\
(1.7744)\end{array}$ & $\begin{array}{c}8.5018 \\
(4.7042)\end{array}$ \\
\hline $\begin{array}{l}{\left[w^{*} /\left(1-\tau^{*}\right)\right] \cdot} \\
(\mathrm{R} \& D / G N P)\end{array}$ & $\begin{array}{c}3.1769 \\
(2.1870)\end{array}$ & & & & \\
\hline $\begin{array}{l}{\left[\tau^{*} /\left(1-\tau^{*}\right)\right]} \\
(\mathrm{R} \& \mathrm{D} / \mathrm{GNP})\end{array}$ & $\begin{array}{l}-5.8209 \\
(2.3508)\end{array}$ & & & & \\
\hline $\begin{array}{l}{\left[\left(W^{*}-\tau^{*}\right) /\left(1-\tau^{*}\right)\right] \cdot} \\
(\mathrm{R} \& D / G N P)\end{array}$ & & $\begin{array}{c}4.2941 \\
(2.0724)\end{array}$ & $\begin{array}{c}3.1769 \\
(2.1870)\end{array}$ & $\begin{array}{c}0.3143 \\
(2.9011)\end{array}$ & $\begin{array}{c}0.3981 \\
(3.0308)\end{array}$ \\
\hline $\begin{array}{l}{\left[\left(\mathrm{w}^{*}-\tau^{*}\right) /\left(1-\tau^{*}\right)\right]^{2}} \\
(\mathrm{R} \& \mathrm{D} / \mathrm{GNP})\end{array}$ & & & & $\begin{array}{l}-4.4628 \\
(2.4171)\end{array}$ & $\begin{array}{l}-4.2460 \\
(3.3159)\end{array}$ \\
\hline $\begin{array}{l}{\left[1 /\left(1-\tau^{*}\right)\right]} \\
(\mathrm{R} \& \mathrm{D} / \mathrm{GNP})\end{array}$ & & & $\begin{array}{l}-2.6440 \\
(2.0200)\end{array}$ & & $\begin{array}{l}-0.2590 \\
(2.7136)\end{array}$ \\
\hline$\hat{\sigma}$ & $\begin{array}{c}0.0497 \\
(0.0062)\end{array}$ & $\begin{array}{c}0.0509 \\
(0.0063)\end{array}$ & $\begin{array}{c}0.0497 \\
(0.0062)\end{array}$ & $\begin{array}{c}0.0487 \\
(0.0060)\end{array}$ & $\begin{array}{c}0.0487 \\
(0.0060)\end{array}$ \\
\hline $\log L$ & 47.1507 & 46.3131 & 47.1507 & 47.9522 & 47.9568 \\
\hline $\mathrm{n}$ & 43 & 43 & 43 & 43 & 43 \\
\hline
\end{tabular}

Note: The columns report coefficients from Tobit regressions in which the dependent variable is the ratio of R\&D expenditures by foreign affiliates of U.S. corporations to the affiliates' expenditures on labor compensation in manufacturing. The variable $(R \& D / G N P)$ represents country $R \& D / G N P$ ratios reported by the National Science Foundation (1991). The variable $\tau^{*}$ represents local statutory corporate tax rates, and $w^{*}$ represents withholding tax rates imposed by foreign countries on royaity payments to the United States. Observations are country-level aggregates of the behavior of all U.S.owned affiliates. Standard errors are in parentheses. 
Table 7

Local Tax Rates and the Own-Intensity of R\&D by Foreign Affiliates of U.S. Corporations, 1989

Dependent Variable: (R\&D by Affiliates for Affiliates/Total R\&D by Affiliates)

\begin{tabular}{|c|c|c|c|c|c|}
\hline Constant & $\begin{array}{c}0.9644 \\
(0.1273)\end{array}$ & $\begin{array}{c}0.9294 \\
(0.0685)\end{array}$ & $\begin{array}{c}0.9750 \\
(0.3068)\end{array}$ & $\begin{array}{c}0.9447 \\
(0.2065)\end{array}$ & $\begin{array}{c}0.8776 \\
(0.4103)\end{array}$ \\
\hline$w^{*} /\left(1-\tau^{*}\right)$ & $\begin{array}{c}0.2654 \\
(0.1333)\end{array}$ & & & & \\
\hline$\tau^{*} /\left(1-\tau^{*}\right)$ & $\begin{array}{l}-0.2048 \\
(0.2028)\end{array}$ & & & & \\
\hline$\left(\mathrm{w}^{*}-\tau^{*}\right) /\left(1-\tau^{*}\right)$ & & $\begin{array}{c}0.2562 \\
(0.1256)\end{array}$ & $\begin{array}{c}0.2654 \\
(0.1333)\end{array}$ & & $\begin{array}{c}0.2362 \\
(0.1509)\end{array}$ \\
\hline $\mathrm{w}^{*}$ & & & & $\begin{array}{c}0.4378 \\
(0.2333)\end{array}$ & \\
\hline$\tau^{*}$ & & & & $\begin{array}{l}-0.3872 \\
(0.5543)\end{array}$ & \\
\hline$\left[\left(\mathrm{w}^{*}-\tau^{*}\right) /\left(1-\tau^{*}\right)\right]^{2}$ & & & & & $\begin{array}{l}-0.1071 \\
(0.2982)\end{array}$ \\
\hline $1 /\left(1-\tau^{*}\right)$ & & & $\begin{array}{c}0.0606 \\
(0.1923)\end{array}$ & & $\begin{array}{c}0.1311 \\
(0.2766)\end{array}$ \\
\hline$\hat{\theta}$ & $\begin{array}{c}0.2527 \\
(0.0435)\end{array}$ & $\begin{array}{c}0.2527 \\
(0.0434)\end{array}$ & $\begin{array}{c}0.2527 \\
(0.0435)\end{array}$ & $\begin{array}{c}0.2550 \\
(0.0439)\end{array}$ & $\begin{array}{c}0.2525 \\
(0.0434)\end{array}$ \\
\hline $\log L$ & -12.1006 & -12.1524 & -12.1006 & -12.5287 & -12.0370 \\
\hline a & 38 & 38 & 38 & 38 & 38 \\
\hline
\end{tabular}

Note: The columns report coefficients from Tobit regressions in which the dependent variable is the ratio of R\&D expenditures by foreign affiliates of U.S. corporations for their own use to the affiliates' total R\&D expenditures. The variable $\tau^{*}$ represents local statutory corporate tax rates, and $w^{*}$ represents withholding tax rates imposed by foreign countries on royalty payments to the United States. Observations are country-level aggregates of the behavior of all U.S.-owned affiliates. Standard errors are in parentheses. 
Table 8

Royalty Tax Rates and Royalty Payments by Foreign-Owned Affiliates in the United States, 1987

Dependent Variable: (Royalties Paid/Total Sales), Foreign-Owned Affiliates

\begin{tabular}{|c|c|c|c|c|c|}
\hline Constant & $\begin{array}{l}-0.0012 \\
(0.0008)\end{array}$ & $\begin{array}{c}0.0005 \\
(0.0011)\end{array}$ & $\begin{array}{l}-0.0004 \\
(0.0008)\end{array}$ & $\begin{array}{c}0.0007 \\
(0.0011)\end{array}$ & $\begin{array}{l}-0.0003 \\
(0.0008)\end{array}$ \\
\hline $\mathrm{R} \& \mathrm{D} / \mathrm{GNP}$ & $\begin{array}{c}0.1100 \\
(0.0432)\end{array}$ & $\begin{array}{c}0.0541 \\
(0.0471)\end{array}$ & $\begin{array}{c}0.0834 \\
(0.0418)\end{array}$ & $\begin{array}{c}0.0529 \\
(0.0458)\end{array}$ & $\begin{array}{c}0.0831 \\
(0.0413)\end{array}$ \\
\hline$w$ & & $\begin{array}{c}-0.0074 \\
(0.0036)\end{array}$ & & $\begin{array}{c}-0.0174 \\
(0.0116)\end{array}$ & \\
\hline$w(1-F T C)$ & & & $\begin{array}{l}-0.0073 \\
(0.0038)\end{array}$ & & $\begin{array}{l}-0.0151 \\
(0.0187)\end{array}$ \\
\hline$w^{2}$ & & & & $\begin{array}{c}0.0342 \\
(0.0375)\end{array}$ & \\
\hline$w^{2}(1-F T C)$ & & & & & $\begin{array}{c}0.0269 \\
(0.0630)\end{array}$ \\
\hline$\hat{\sigma}$ & $\begin{array}{c}0.0018 \\
(0.0003)\end{array}$ & $\begin{array}{c}0.0016 \\
(0.0003)\end{array}$ & $\begin{array}{c}0.0016 \\
(0.0003)\end{array}$ & $\begin{array}{c}0.0016 \\
(0.0003)\end{array}$ & $\begin{array}{c}0.0016 \\
(0.0003)\end{array}$ \\
\hline $\log \mathrm{L}$ & 77.1371 & 79.3389 & 79.1162 & 79.7464 & 79.2077 \\
\hline 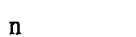 & 27 & 27 & 27 & 27 & 27 \\
\hline
\end{tabular}

Note: The columns report coefficients from Tobit regressions in which the dependent variable is the ratio of royalties paid by foreign-owned affiliates to the affiliates' total U.S. sales in 1987 . The variable (R\&D/GNP) represents country R\&D/GNP ratios reported by the National Science Foundation (1991). The variable $w$ represents the withholding tax rate imposed by the United States on royalty payments from the United States. The variable FTC equals unity if an investor's home country taxes worldwide income and grants foreign tax credits to its residents, and equals zero otherwise. Observations are country-level aggregates of the behavior of all foreign-owned affiliates. Standard errors are in parentheses. 
Table 9

Royalty Tax Rates and R\&D Intensities of Foreign-Owned Affiliates in the United States, 1987

Dependent Variable: (R\&D/Manufacturing Labor Compensation), Foreign-Owned Affiliates

\begin{tabular}{|c|c|c|c|c|c|}
\hline Constant & $\begin{array}{l}-0.1844 \\
(0.0697)\end{array}$ & $\begin{array}{l}-0.1716 \\
(0.0565)\end{array}$ & $\begin{array}{l}-0.1345 \\
(0.0456)\end{array}$ & $\begin{array}{l}-0.1625 \\
(0.0547)\end{array}$ & $\begin{array}{l}-0.1387 \\
(0.0472)\end{array}$ \\
\hline $\mathrm{R} \& \mathrm{D} / \mathrm{GNP}$ & $\begin{array}{l}14.6146 \\
(3.5479)\end{array}$ & $\begin{array}{l}12.1191 \\
(2.9640)\end{array}$ & $\begin{array}{l}10.5524 \\
(2.3883)\end{array}$ & $\begin{array}{l}12.2114 \\
(2.8594)\end{array}$ & $\begin{array}{l}10.6242 \\
(2.4134)\end{array}$ \\
\hline$w(\mathrm{R} \& \mathrm{D} / \mathrm{GNP})$ & & $\begin{array}{c}30.8403 \\
(11.9140)\end{array}$ & & $\begin{array}{c}-5.6039 \\
(42.1940)\end{array}$ & \\
\hline $\begin{array}{l}\text { w(1-FTC) } \\
\text { (R\&D/GNP) }\end{array}$ & & & $\begin{array}{c}45.4557 \\
(10.0257)\end{array}$ & & $\begin{array}{c}72.9530 \\
(63.4897)\end{array}$ \\
\hline$w^{2}(R \& D / G N P)$ & & & & $\begin{array}{c}128.6451 \\
(142.4354)\end{array}$ & \\
\hline $\begin{array}{l}\mathrm{w}^{2}(1-\mathrm{FTC}) \cdot \\
(\mathrm{R} \& \mathrm{D} / \mathrm{GNP})\end{array}$ & & & & & $\begin{array}{c}-93.2700 \\
(212.7782)\end{array}$ \\
\hline$\hat{\sigma}$ & $\begin{array}{c}0.1335 \\
(0.0225)\end{array}$ & $\begin{array}{c}0.1094 \\
(0.0190)\end{array}$ & $\begin{array}{c}0.0891 \\
(0.0153)\end{array}$ & $\begin{array}{c}0.1060 \\
(0.0185)\end{array}$ & $\begin{array}{c}0.0892 \\
(0.0154)\end{array}$ \\
\hline $\log L$ & 6.7117 & 9.2883 & 13.0824 & 9.6807 & 13.1794 \\
\hline $\mathrm{n}$ & 27 & 27 & 27 & 27 & 27 \\
\hline
\end{tabular}

Note: The columns report coefficients from Tobit regressions in which the dependent variable is the ratio of the U.S. R\&D expenditures of foreign-owned affiliates to the affiliates' total U.S.

manufacturing labor compensation in 1987. The variable (R\&D/GNP) represents country $R \& D / G N P$ ratios reported by the National Science Foundation (1991). The variable w represents the withholding tax rate imposed by the United States on royalty payments from the United States. The variable FTC equals unity if an investor's home country taxes worldwide income and grants foreign tax credits to its residents, and equals zero otherwise. Observations are country-level aggregates of the behavior of all foreign-owned affiliates. Standard errors are in parentheses. 